\title{
Five Framings - One Entity? The Political Ethics of Human Embryonic Stem Cells
}

\author{
Torben Hviid Nielsen
}

Following their initial derivation in 1998, human embryonic stem cells have been presented in five dominant framings. The original framings as a breakthrough in basic research and a medical hope were both intended and orchestrated to anticipate and overrule the old bioethical concerns. The third framing nonetheless questioned the legitimacy of the bare laboratory research from day one.Two subsequent framings presented adult stem cells as Nature's own solution and cloning as Mankind's technofix solution, i.e. as alternative points of passages to the ethical concerns, but they did not succeed to regain the agenda and the public discourse. The five framing are thus elements of a still unclosed encounter over-determined by (bio)politics. Finally the framing of "facts" of nature, technological "artefacts" and social "construct" is discussed in the light of recent interpretations of stem cells as "state" rather than as "entity",thus indicating that no single entity is to be found behind the five framings.

Key words: bioethics, biotechnology, stem cells

The 1998 Summer-issue of Technology Review disclosed the ongoing pioneer research on human embryonic stem cells under the front-page heading "Biotech Taboo"... "The troubled Hunt for the ultimate Cell,... that could be used to grow any type of human replacement tissue" (Regalado, 1998: frontpage, 34). Barely a year and a half later the front-page of the 1999 Christmas-issue of Science promoted stem cells as the "Breakthrough of the Year,... capturing the Promise ofYouth" (Vogel, 1999: front- page, 2238-2239). In November 1999 a committee under the American Association for the Advancement of Science concluded that stem cell research "raises ethical and political concerns, but these are not unique to stem cell research" (AAAS, 1999: iv). Two years later a committee under the National Research Council stated that "the stem cell debate has led scientists and nonscientists alike to contemplate profound issues, such as who we are and what makes us human beings" (NRC, 2001: xi). 
Human embryonic stem cells have together with cloning-become the most promising, as well as the most controversial, amongst the many new and emerging biotechnologies. After they left the laboratories in 1998 to become part of public debate five framings have dominated their presentation and discussion. The first public pronouncement was well orchestrated as progress in basic science, and the second framing as a medical hope was often presented as just the other, applied, side of it. The two original framings were partly intended to prevent the reoccurrence of traditional ethical concerns, which nevertheless questioned the first two from the very beginning. Subsequently, the scientific community itself suggested two "solutions" to the reoccurring ethical concerns: in a fourth framing offering the potentials of the adult stem cells as Nature's own solution and in a fifth framing offering therapeutic cloning as Mankind's techno-fix.

The main topic is the intended creation of and the relation between the five framings, their interplay in the public narrative and discourse, as well as the partly unforeseen and unintended consequences thereof. None of the five framings have succeeded to bring a closure to the controversy. All remain part of the still vibrant scientific and public debate, but they are utilized in favour of evaluations so varied and regulations so conflicting that compromises are difficult to formulate and attain. They also appear diverse and partly apart, to the extent where geneticist and biologists are now questioning whether one and the same well defined biological entity is to be found behind all of them.

Pioneer STS-articles by Trevor Pinch and Wiebe Bijker conceptualized and retold the story of the high-wheel Ordinary bicycle and Bakelite as the framing, design and eventually production of new technological artefacts or inventions. After decades of competition between a variety of designs for the bicycle and methods for the production of prebakelite plastic, the high-wheel Ordinary bicycle and Baekeland's patents of 1907 finally brought success to a single framing and design and thus eventually also closure to the flexibility and controversies (Pinch and Bijker, 1989; Bijker, 1989). The term "framing" is throughout this article used in relation to the public representation of an entity of nature, such as in media-studies (Evans, 2002); to the mobilization of collective actors and social movements, such as in the social sciences (Benford and Snow, 2002) - not, as in the case of Pinch and Bijker, to designate the design and creation of technological artefacts. The eventually successful high-wheel bicycle and Bakelite both had their possible alternative framings and artefacts (as e.g. the Kangaroo bicycle and Ivoride/Xylonite or Celluloid), whereas the five framings of human embryonic stem cells, to be discussed below, all assume or presume to address different aspects and evaluations of the very same biological entity. Instead of diverse framings leading to different technological artefact, the same entity of nature is presented to the public in five different framings indicating different horizons and valuations. Up until now, none of the five framings have become dominant and "successfully", able to exclude the others and close the flexibility and controversy, in the same way as the high-wheel bicycle and Bakelite did. 


\section{First framing. The Derivation of a Scientific Discovery}

During the years from 1995 to 1998 labs in Wisconsin and Baltimore were the sites of the initial derivation of human embryonic stem cells, but their first public presentation took place via internet from the rented offices of their coordinator and financier, the entrepreneur Dr. MichaelWest at Geron Corporation, who had licensed the cells worldwide, orchestrated the framing of their first public announcement as a "scientific discovery" and "progress in basic research" very thoroughly. Two press releases from the company provided the key background information for the printed press' front-page news that "Scientist Found Cells at Root of Human Life" on November 6, 1998 (The New York Times). The press releases referred back to two prestigious scientific publications: An article in Science by professor James A. Thomson and colleagues from University of Wisconsin, who had isolated human embryonic stem (hES) cells from the inner cell mass of human embryos at the blastocyst stage (Thomson et al., 1998), and another article in Proceedings of the National Academy of Science by professor John D. Gearhart and colleagues from John Hopkins University, Baltimore, who had isolated human embryonic germ (hEG) cells from foetal tissues obtained from terminated pregnancies (Shamblott et al., 1998).

The passage from the scientific periodicals via the press releases to the frontpage news was, however, also an essential translation and reframing. Stem cells, especially from bone marrow, had been known and used in cancer treatment since the 1950s, and embryonic stem cells had been derived from mice in 1981 (Evans et al., 1981) and from primates in 1995 (Gearhard et al., 1995). The "novelty" presented in the scientific publications was thus neither the existence of stem cells as such, nor of embryonic stem cells or even of human embryonic stem cells, but merely the successful "derivation" of human embryonic stem cells, which consequently was presented as technical and practical knowhow more than as scientific and systematic knowledge.

The two articles do not have the aura of a new theoretical insight nor do they proclaim any controversial breakthrough. The definition of the cell lines and the operational criteria for their derivation are both conveyed unchanged from the preceding experiments with mice and primates. The essential content of the two articles is a summary and documentation of research-protocols with references to preceding studies. Description and documentation of practical procedure in the laboratories take precedence over conceptual clarification and explanations. Large passages of the two articles thus resemble a mix of cookbook and manual, conceptual trivialities and complicated technicalities: those were the ingredients and this is how we proceeded at the lab-bench. By way of a not untypical example:

Cells were grown in DMEM (GIBCO/ BRL) supplemented with $15 \%$ fetal bovine serum (HyClone), 0,1 mM nonessential amino acids (GIBCO/BRL), 0,1mM 2-mercaptoethanol (Sigma), 2 $\mathrm{mM}$ glutamine... Cultures were grown in $5 \%$ or $8 \% \mathrm{CO}_{2}, 95 \%$ humidity and were routinely passaged every 7 days after disaggregation with $0.05 \%$ 
trypsin/0.53 mM EDTA (GIBCO/BRL) or $0,25 \%$ trypsin at $37^{\circ} \mathrm{C}$ for $5-10 \mathrm{~min} .$. Cells prepared for cytogenetic analysis were incubated in growth media with $0.1 . \mu \mathrm{g} / \mathrm{ml}$ of Colcemid for 3-4 hr, trypsinized, resuspended in $0.075 \mathrm{M}$ $\mathrm{KCl}$, and incubated for $20 \mathrm{~min}$ at $37^{\circ} \mathrm{C}$, then fixed in 3:1 methanol/acctic acid (Shamblott et al., 1998:13727).

The articles do not claim to have found or discovered any new or even unexpected entity or substance, but rather to have demonstrated that an expected entity can be kept and maintained in a certain form: isolated, cultivated and expressed. The two research-teams had successfully adapted and replicated or copied in human cells, what had previously been attained in cells from mice and primates. The articles thus constituted human embryonic stem cells as a new object for science analogous to the way Gregory Mendel constituted genetics (and Crick \& Watson later DNA) as objects for science (Foucault, 1971), but neither theoretical implications nor practical applications were part of the presentation.

The triangle of collaboration between the private company Geron, the partly public universities and their partly outsourced research-teams was a response to the political reality, that the USA had had a de facto ban on public funding of research since 1996 "in which a human embryo or embryos are destroyed, discarded, or knowingly subjected to risk of injury or death greater than that allowed for research on fetuses in uteri." Congress had taken the decision ad hoc as the Dickey-Wicker amendment to Department of Health and Human Services annual budget - and against the recommendations of the National Institute of Health and the Clinton-adminis- tration. As only the use of public funding was forbidden, a paradoxical consequence was, however, quoting Dr. Ronald Green, a key advisor to the Clinton-administration.

... [that] although much of the previous animal research on ES cells that had led to Thomson's achievements was federally financed, the commercial benefit would now be in private hands (Green, 2001: 9).

Geron Corporation had been founded by Dr. Michael West in 1990. Following the publication of the derivation of embryonic stem cells from primates in 1995, Geron had funded the research of Thomson and Gearhart, as well as Professor Roger Peterson, University of California, San Francisco - considered by many the most promising candidate to succeed (Regalado, 1998: 38). The investments in funding for licenses turned out to be an immediate financial success. Two applications for patents were filed well in advance of the scientific publication and subsequently approved. On the very day of announcement, stocks rose from $\$ 6$ to $\$ 23$. One month later, convertible debentures worth $\$ 15$ million were sold to venture capitalists.

Yet, a fourth type of text had preceded the triangle of publications behind the first public announcement. The articles in the prestigious scientific journals both rounded off with reservations characteristic of the genre, in the words of Thomson and colleagues: "Substantial advances in basic developmental biology are required to direct Es cells efficiently to lineages of human clinical importance" (Thomson et al., 1998: 1147). Two patent-applications were, however, filed well in advance, and they presented the findings with a confidence and firm- 
ness fare from the modesty and reservations in the scientific articles. Both applications were "continuation-in-part" of earlier applications. They were more detailed, fare longer than the articles and the "Scientists" were completed in the standard formula as "Inventors". Gearhart's application (United States Patent, 1998a) had the largest number of formal "Claims", thirty-six, all concerning methods of producing and/or maintaining "human pluripotent embryonic germ cells". The eleven claims in Thomsen's application (United States Patent, 1998b) were presented in another "logic". The first eight claims cover different variants of "a purified preparation of pluripotent human embryonic stem cells", the two next methods of isolating such cell lines, and last the cell line developed by the method.

The rationale behind the comprehensive claims is the quest for a maximum of legal protection. And the criteria for patentability may have determined even the choice of the key concept or technical term "derivation". The term "derivation" was not used in the articles reporting the previous use of identical procedures and techniques on mice and primates; the key terms here were "isolation" and "establishment", partly used as synonyms. But "derivation" was the key term also in the 1997-article announcing the cloning of a "viable offspring", the sheep Dolly (Wilmut et al., 1997). Following the new terminology or the new use of old terms, human embryonic stem cells and cloned sheep were both presented as "derived". The two prominent cases are only examples of a general trend in the prestigious scientific periodicals during the 1990s (see Fig. I.). "Isolation" and "establishment" were the most frequently used terms in the first half of the decade, but during the second half "derivation" took over as the most frequent. The significant change took place just around the years when the sheep Dolly and the human embryonic stem cells both were termed as "derived".

The new trend might be a momentary conjuncture, but the relative increase in the use of the term "derivation" at the expense of "isolation" and "establishment" during the 1990s is both significant and meaningful. The term "derivation" was increasingly used to describe the isolation, cultivation and expression of embryonic stem cells, as well as the cloning of viable offspring, i.e. two very different phenomena, but the two most promising and controversial of the many new biotechnologies. The new tendency is "real", but we don't know the degree to which it reflects substantial changes in research priorities, mere changes in editorial criteria or even merely a change of habitual wording. Asked for the causes of the change, the typical answer from a handful of prominent researchers in the field was that they had not previously been aware of any such change; that the change nevertheless seemed plausible, but that it did not require any special explanation. "It is quite simply the concept we use." The diverse and escalating use of the term "derivation" might appear irrelevant or even trivial to the working scientists, but the precedence from the terms prehistory in patenting of organic chemistry is well known and acknowledged among lawyers. The "derivation" of a substance was sufficient to satisfy one of the three general, but crucial, criteria for patentability. Although still a product of nature, since it 
Figure I. From isolation towards derivation.

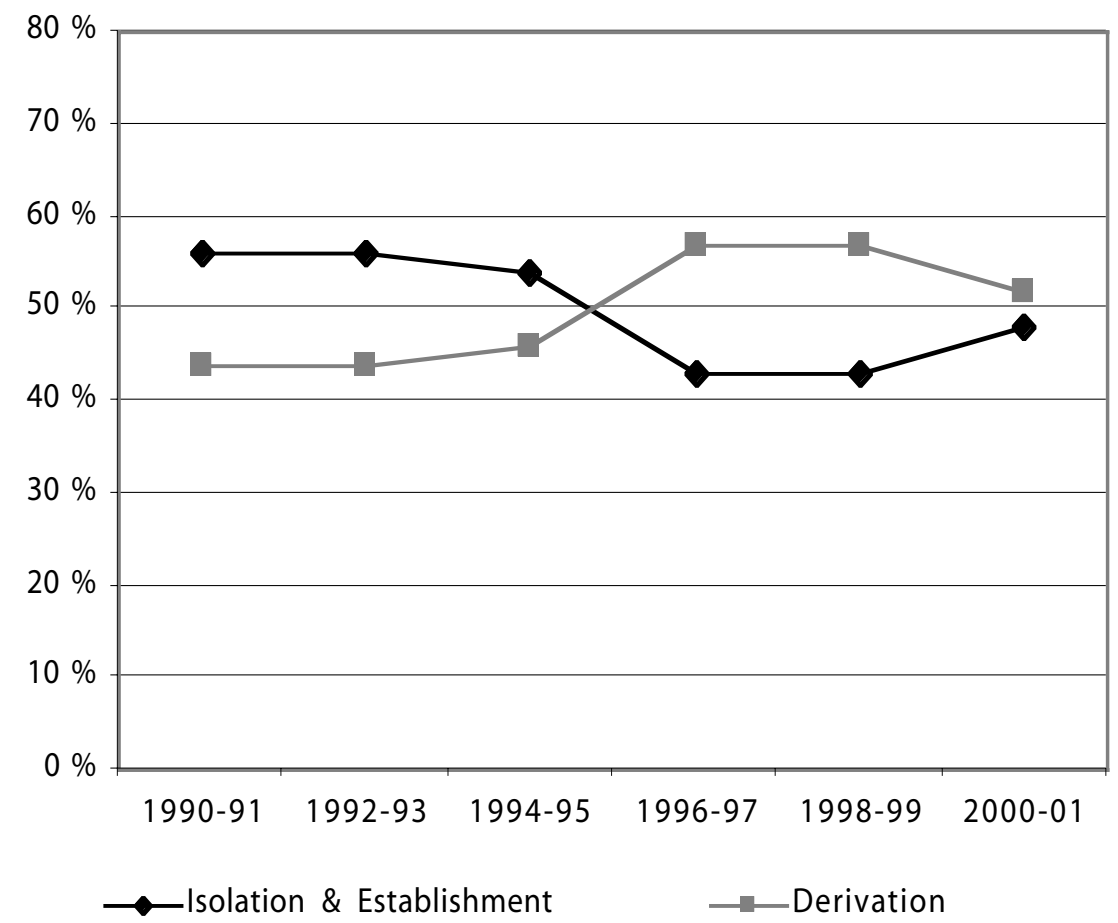

The relative occurrence of "isolation" and "establishment" versus "derivation" in Nature, Proc. Nat. Acad. Sci. and Sciene, 1990-2001.

Source: Data-search in "Titles" in the three periodicals from 1990 to 2001.

Truncations used were "Isolat\#", "Establish\#" and "Deriv\#".

$\mathrm{N}=1137$, with 266 in 1990-91, 214 in 1992-92, 209 in 1994-95, 161 in 1996-97, 162 in 1998-99 and 125 in 2000-2001.

would not have existed in the new form without the intervention of science, a derived entity was considered also a product of ingenuity and thus a patentable invention. ${ }^{1}$

\section{Second Framing. The Promise of a Regenerative Medicine}

The second framing of the human embryonic stem cells as a medical hope, the promises of regenerative medicine, was often presented as just the other side of the progress in basic knowledge, as the step from "pure" to "applied" science. The principal agents were the same, but alongside the scientific community and venture capitalists the appeal was directed more towards the general public and authorities as The National Institute of Health. Both steps in this widespread and still persuasive, but very traditional, 
presentation of the novelty are, however, deceptive. Down to the choice of basic terminology desired ends were built and calculated into the "discovery" from the first design of the laboratory studies. The "application" is also a redefinition or translation of health and illness, life and death, from existential and social terms.

The applied potential of embryonic stem cells was presented as the biotechnical mean to retain, modify or even undo apoptosis, i.e. the programmed cell death, which (beginning with Leonard Hayflick and Paul Morehead's proposal in 1961 that "cancerous" cell lines were the only immortal cells, whereas "normal" cells had a finite lifespan) had replaced the immortality of cell lines as the paradigmatic understanding. Social death and euthanasia had, according to Hannah Landecker, become
"cellular, even to the extent that a cell can commit altruistic suicide or die by interaction with another cell in the Kevorkian option"... Death was rede- fined as a mixed metaphor, marking a "radical shift in biological knowledge in the late twentieth century, from an oppositional model of life and death to one in which cell death is integral to the ongoing life of the organism." (Landecker, 2003: 23-24).

All stem cells, also adult, do produce the enzyme telomerase, which was isolated for the first time in 1989 and maintains the non-coding bits of DNA attached to the end of each chromosome (Dwayne et al., 1989). With a biochemical explanation for philosophers, telomerase "resets the cell's chromosomal clock" and "prevents the timed death suffered by most differentiated cells". Stem cells hence have the capacity for "prolonged self-renewal"; they are able to produce "at least one type of highly differentiated or specialized descendant." (Green, 2001: 35) Yet, the emerging new paradigm ascribes three additional capacities to embryonic stem cells: they are pluripotent (able to differentiate to all types of tissues in the body); they are malleable (can be manipulated without loosing the structure of the cell); and they are immortal (able to continue differentiation apparently unlimited) (Weismann, 2000; Fuch and Segre, 2000; Chiu and Rao, 2003). The three unique capacities were the background for $\mathrm{Sci}$ ence's presentation of human embryonic stem cells as the 1999-breakthrough of the year.

"If it lives up to its early promise, it may one day restore vigour to aged and diseased muscles, hearts, and brains - perhaps even allowing humans to combine the wisdom of the old age with the potential of youth"... [They] "may one day be used to treat human diseases in all sort of ways, from repairing damaged nerves to growing new hearts and livers in the laboratory; enthusiasts envision a whole catalog of replacement parts" (Vogel, 1998: 2238).

The three potentials considered unique to embryonic stem cells add up to the scenario of "regenerative medicine", which enlarges the scope of medical therapy "from simply halting the progression of acute or chronic disease to include restoration of lost organ functions". Bypassing surgery's interventions in the body, as well as the side effects of pharmaceuticals, regenerative medicine will - according to Dr. Thomas Okarma, who had succeeded West as CEO of Geron - "be a totally new value paradigm for clinical therapeutics." Okarma was thus able to revolve the moral concern and argument against the bioethicists themselves. "Not to develop the technol- 
ogy would do great harm to over 100 million patients in the U.S. alone." (Okarma, 2001: 3). The number originates from an overview over the potential US patient population for stem cellbased therapies, which is estimated 58 million with cardiovascular diseases, 30 million with autoimmune diseases, 16 million with diabetes, 10 million with osteoporosis, and 8.2 million with cancer (Perry, 2000). The twisted optic acquits the optimistic scientists in order to make the sceptic bioethicists, willing to deprive one third of the population their cure, the real threat to real morality. Stem cells thus acknowledge or confirm the cellular level as the space or place of death (Landauer, 2003), but besides they offer themselves as the biomedical means able to postpone or ultimately undo cellular death.

Geron's strategy has been characterized as "a redefinition of the human and the social in which social responsibility for health risks becomes biologized in order to be industrialized" (Franklin, 2003: 123), a characterization in accordance with Technology Review's scenario of "the human body shop" a decade from now:

....an elderly man gets the grim news that his heart is rapidly decaying and that the left ventricle - the chamber that squeezes blood out to the body needs to be replaced. His physician takes a biopsy of the heart cells that are still healthy and ships the tissue to a lab that is really an organ factory. There, workers use that patient's own cells and special polymers to fashion and grow a replacement part-certified by the original manufacturer. In three months, the new ventricle is frozen, packaged and sent to the hospital, where the patient undergoes a standard surgical procedure: the insertion of a living implant created from his own tissue (Garr, 2001: 73).

The aura is high-tech, but the medical use of embryonic stem cells is presented as low intervention. The stem cells are "organic", i.e. the body's own internal healing mechanisms, "personal", i.e. one's own, and "clean", i.e. uncontaminated. But the real "magic" is the promise to break the arrow of time. "The immortal Cell" is a shortcut to "The eternal Life". Destiny and fate are no longer untouchable. Regenerative medicine is high-tech utilization of the individuals own embryonic stem cells as cure against the otherwise unavoidable apoptosis of the cells. Science and medicine promise to accomplish here and now, what religion in the past barely believed possible in the next world. Life is about to become reversible or restorable, the permanent beginning or the continuous renewal. The hopes of "there and then" will become the reality of "here and now" (Alexander, 2003; Hall, 2003).

Medical hopes and expectations are high and hype, but the "applied" reality is - at least up to now - a "proof of principles". Experiments in vitro and with model-animals confirm the principle: new tissues can differentiate and old ones can be restored. The step from scientific principle to medical practice is, however, also a question of degree and type of differentiation, density and intensity, compatibility, targeting, and possible side-effects. The old bloodforming stem cells in bone marrow (HSC) are still "the only type of stem cell commonly used for therapy" (National Institute of Health, 2003).

The severe shadow and potential backlash hanging over the medical hope is over-selling, promising too much too 
fast. Even the pioneering-scientists soon warned of the backlash likely to come. As early as 2002, Prof. Thomson was quoted for not "looking forward to the backlash 3 years from now when people say, 'What happened to stem cells?' ...We need to educate the public that science takes a long time" (Holden and Vogel, 2002: 2119). But entrepreneurs, such as West, were eager to insist on the nonscientific, and thus unnecessary, character of all obstacles. "We have the basic discoveries within our reach to put regenerative medicine into the hand of physicians. We are missing only two components - an organized effort and time" (West, 2003: 220).

\section{Third Framing. Playing God? Old (Bio)ethical Concerns in New Voices}

Emphasizing the progress in basic research and the hope for cure of illness, the two initial framings were also anticipating strategies intended to trump and overrule the expected moral concerns. The two framings succeeded to counterbalance, but they were unable to neutralize the critique, which questioned the very legitimacy of the basic laboratory research from day one. If science was about to replace religion as the explanation of life, then Christian (or Creationist) religion was soon to return accusing the new technologies of "playing God". The most prominent opponent was the Vatican, but the recently inaugurated U.S. president, Republican George W. Bush, followed along the same line. On August 9, he addressed the nation broadcast primetime from Crawford Texas to discuss the "complex and difficult issue, an issue that is one of the most profound of our time" (Bush, 2001). His speech hinted to and utilized the two arguments most frequently used by opponents and sceptics.

The first and foremost argument gains its immanent strength by ascribing $a$ special moral status to the embryo. The Christian background is manifest in the President's characterization of the embryo as "a sacred gift from our Creator". Most believers in and users of the argument consider the status of the embryo as emerging gradually (increasing from some time after fertilization to the full born baby), but a more radical version consider the status as absolute and beginning from fertilization. The President's wording of the argument alludes to the absolute version. "The beginning of Life" should also be "The end of Science." But the President is politician enough not to take an explicit stand in the controversial dispute between the two versions splitting the supporting religious communities.

The second moral argument alluded to by the President is a more philosophical and formal maxim as regards the relation between means and ends. The maxim is usually traced back or ascribed to Immanuel Kant's practical imperative, but the President's version is another. "Even the most noble ends do" in the wording of the President "not justify any means". The Presidents open-ended version is an anticipation of its own application. The casuistic question is whether the "most noble ends" (as a healthier or prolonged life) can justify "any means" (as the destruction of embryos to harvest required stem cells)?

A strict interpretation and radical application of the two arguments prescribes a "No" or a "Ban" to all research using human embryonic stem cells. The 
status of the Cell is violated and the maxim of the Philosopher infringed. Endorsed with an absolute status the "embryo" resists its own use in science. The technologically unavoidable is consequently morally untouchable, the required source morally problematic. Ethics stands versus science and science versus ethics. No compromise seems possible. But instead of the absolute ban indicated by his rhetoric and supposed by his arguments the president concluded

...that we should allow federal funds to be used for research on these existing stem cell lines (more than 60 lines as a result of private research), where the life and death decision has already been made (Bush, 2001).

The unexpected conclusion was intended as a political balance offering concessions to the most influential interest-groups and their lobbyists: the proponents were offered (some) stem cell lines to work with, and the opponents were assured that no new demand for embryos would be created. Both sides were, however, soon to designate their respective concessions as unsatisfactory. Scientists complained that the available stem cell lines were too few and not pure enough. The religious communities accused the use of already existing lines of being a double moral standard and even bioethicists, such as Arthur Caplan, denounced the decision as a "fuzzy logic" utilized by the administration in "a political calculation to use opposition to stem-cell research and cloning as a low-risk stalking horse to advance its anti-abortion agenda and secure support among its most avid antiabortion constituents" (Caplan, 2004).

As decided upon, but unsettled and postponed, human embryonic stem cells remained an issue also during the next presidential campaign in 2004. The Democratic candidate John Kerry promised to "overturn the ban on federal funding of research on new stem cell lines, ... he will allow doctors and scientists to explore their full potential with the appropriate ethical oversight. Patients and their families should no longer be denied the hope that this new research brings" (Kerry and Edwards, 2004). Kerry utilized the first two of the five framing discussed here, i.e. science as a necessary precondition for useful medicine. The five arguments in the press release stating his position were thus able to circumvent the controversial ethical issues. The first argument was political, an appeal to consensus: "Stem cell research has broad bipartisan support." The last argument concerned competitiveness: U.S.A. is "losing leadership in stem cell research". The three remaining arguments were all technical criticisms of Bush's decision as not only insufficient, but also unimplemented. Fewer cell lines than promised were available; they were contaminated with mouse cells; and other cells were not available. Apart from a few empty insertions, ethical issues were unmentioned - apparently considered an argument of the opposition so profound that the best tactic was to steer clear of it.

After the re-election and revitalization of the Bush-administration in the autumn of 2004, the disagreement as to whether the two first or the third framing, the scientific and medical progress or the moral concern, should gain dominance was continued on state level. The two leading states in stem cell research, the republican governed California and 
the democratic governed Massachusetts, both passed state laws permitting and offering public funding for research on human embryonic stem cell.

\section{Forth Framing. Adult Stem Cells as Nature's Own Solution?}

The first two framings were influential, but they did not succeed to avoid, neutralize or overtrump the old and anticipated ethical considerations. The focal public debate became a partial revival of old ethical concerns, a new version of the debate on embryonic research, but novel and unique to human stem cells was the way science itself suggested new "technical" solutions to the old ethical concerns. In two subsequent steps sci- ence partly regained the framing and the agenda, first by the idea of adult stem cells as Nature's own solution, then by therapeutic cloning as Mankind's technofix to the ethical challenges. Using the language of Actor-Network-Theory both were framed or presented as alternative points of passage (Christiansen, quoted by Kater, 2004). The entrepreneurs, the scientists and their labs partly regained the scene and the agenda from public policy and ethical concerns.

The very article in Science that promoted stem cells as the breakthrough of the year, also pointed to another "astonishing development that occurred in 1999 (and that) may ease the ethical dilemma".

In defiance of decades of accepted

Figure 2. The Ontological Hierarchy of Stem Cells.

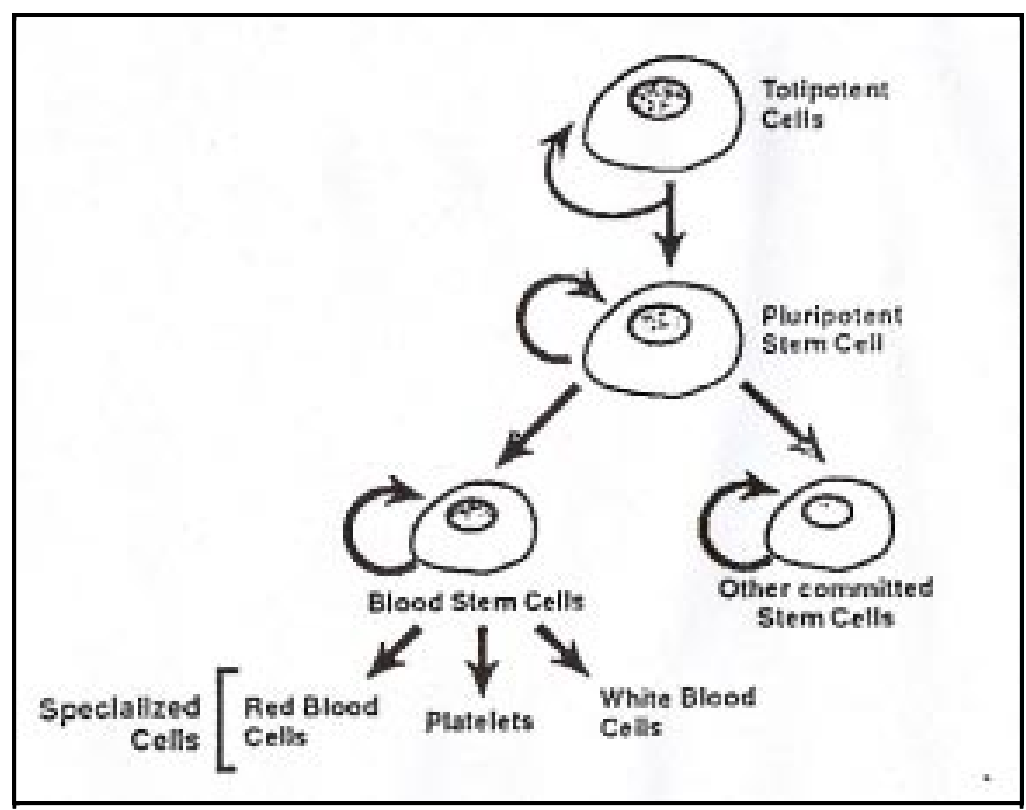

Source: The National Institute of Health, Primer, 2002. 
Figure 3. The Plasticity of Adult Stem Cells. "Too good to be true?"

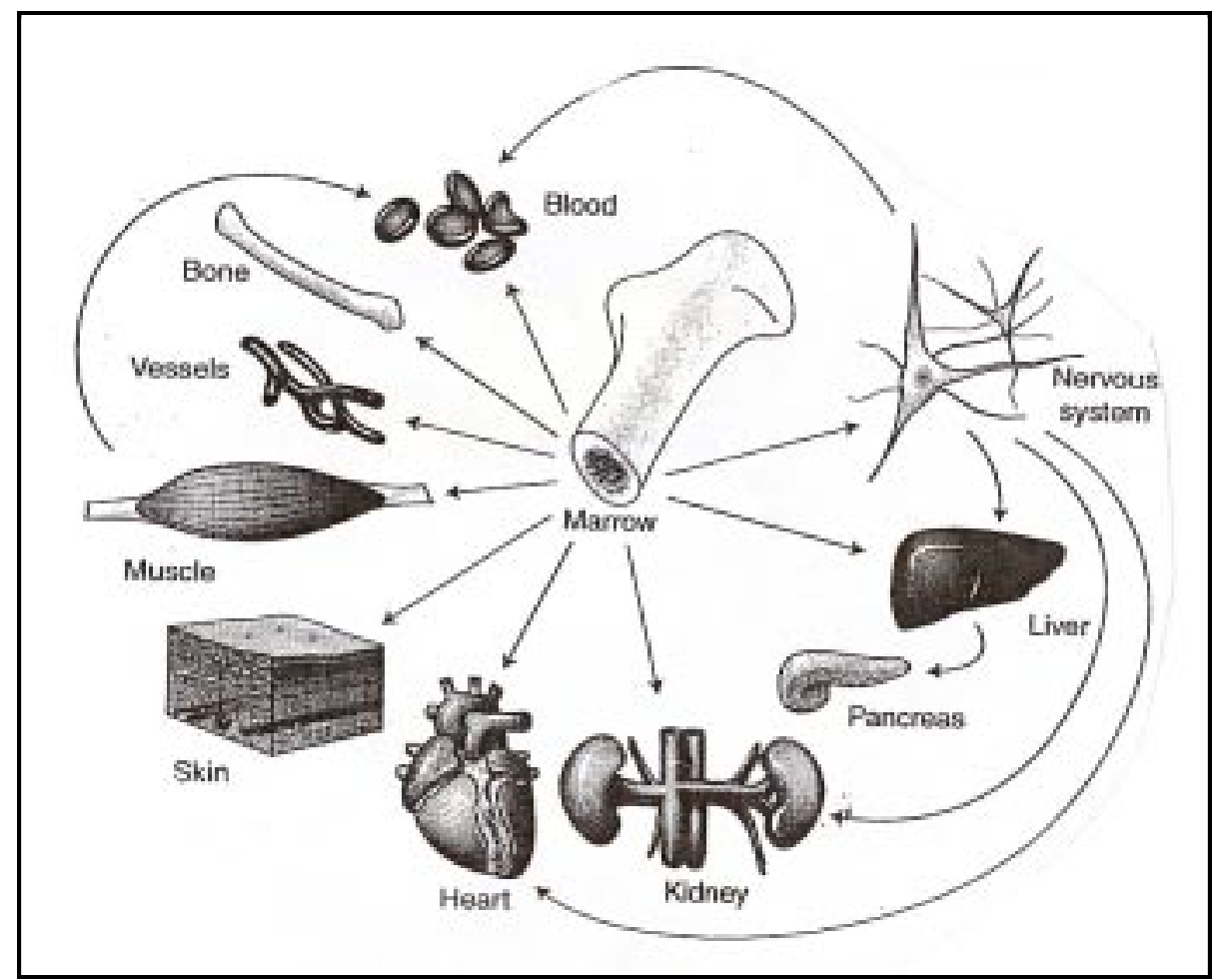

Reprinted with permission from Holden \& Vogel, SCIENCE 296: 2126-2129 (2002).

Illustration by C. Slayden. Copyright 2002 AAAS.

wisdom, researchers in 1999 found that stem cells from adults retain the youthful ability to become several different kinds of tissues: Brain cells can become blood cells, and cells from bone marrow can become liver (Vogel, 1999: 2238).

If it could be demonstrated that adult stem cells had the same (or equivalent) potentials as the embryonic, they would allow to obtain the advantages of stem cells without the use of embryonic cells, and could thus be framed as "Natures own solution" to the reoccurring ethical concerns. Even Thomson kept the theoretical possibility open: "If it becomes possible to derive an ES cell line from a source other than an embryo, ethical controversies surrounding hES cells would greatly diminish" (Thomson, 2001). Partly funded and eagerly monitored by politicians sceptical to research on embryonic stem cells, researchteams speeded up their work on adult stem cells. During 2001 examples appearing to prove the principle were reported continuously (Clark et al., 2001; Colter et al., 2001; Scolding, 2001). On June 21, 2002 Science illustrated the plasticity "too good to be true", ... "that stem cells from a variety of tissues can produce 
progeny in different organs" (Holden and Vogel, 2002: 2126).

Researchers and scientists did, however, disagree no less and no less severely than the bioethicists. The National Institute of Health's authoritative and widely used Primer thus initially reproduced the old "accepted wisdom" ranking stem cells in a one-way "ontological" hierarchy, which prescribed a moral dilemma for anyone ascribing a special moral status to the embryo. The closer to the biological origin, the greater the medical potentials - and the more suspect the morality!

The N.I.H. has since changed the primer also in order to reflect the possible potentials of adult stem cells better. Figure III was omitted in an update of 3.17.2002 and replaced by the addition that "until recently, there was little evidence that stem cells from adults could change course and provide the flexibility that researchers need in order to address all the medical diseases and disorders they would like to. New findings in animals, however, suggest that even after a stem cell has begun to specialize, it may be more flexible than previously thought".

Theoretical arguments in favour of the hierarchical necessity were mostly voiced by developmental biologists and embryologists. Typical is Stephen Jay Gould's argument for a "progressive specification and differentiation."

The very structure of material reality imposes a principle of trade-offs in both nature and human affairs... We have, in short, traded regenerative capacity for the undeniable evolutionary advantages of maximal complexity... Unfortunately, von Bauer's law, and nature's broader structural rules of trade-off between complexity and flexibility, give us no alternative to embryonic stem cells for now (Gould, 2001).

Highly esteemed scientists conceptualised and interpreted the potentiality of adult stem cells as a closed "theoretical impossibility" visualised as an "irreversible hierarchy", as well as an open "empirical possibility" visualised as an "emanating star". Different levels of abstraction and conceptual traditions are at stake, but the two positions and hypotheses can not both be the whole truth. The still unsettled disagreement resembles the state of internal "anomie" often preceding a new paradigm, more than the everyday routines of an accepted "normal-science" (Kuhn, 1962).

\section{Fifth Framing. Therapeutic Cloning as Mankind's Techno-fix?}

Following the dubious and doubtful presentation of adult stem cells as Nature's own solution, cloning and parthenogenesis were soon framed and presented as Mankind's own techno-fix solution and a second alternative point of passage to the relentless moral concerns.

On November 25, 2001, Advanced Cell Technology (A.C.T.), Worchester, Massachusetts announced to the public that they had succeeded in creating the first human embryo using cloning techniques. Two techniques had been used, both combining a human egg with the person's own cells in order to provide stem cells. A technique á la Dolly replaced the genetic material of human eggs with that of adult cells. Eleven attempts used adult skin cells, eight cumulus cells. None of the eggs with skin cells survived to divide, whereas three eggs with cumulus cells divided once or twice 
before they died. The second and most successful technique was, however, parthenogenesis, i.e. a chemical stimulation of eggs to divide without fertilization. Twenty-two attempts were made, six eggs lived and divided for up to five days, but all died before stem cells ready to be harvested were formed.

Key players had moved from Geron to A.C.T, now headed by the former CEO of Geron Dr. West, and the modus and moment of going public was no less orchestrated than Geron's initial announcement of the derivation. The trinity of information, i.e. periodicals, press releases and mass media, was thus intended as a blue print of the initial success, but the prestigious Science and Proceedings of the National Academy of Science were substituted by a prepublication of the January 2002 issue of the popular Scientific American (2002) and a "Rapid Communication" in the new web-journal E-biomed: The Journal of Regenerative Medicines (Cibelli et al., 2001). Lacking the scientific backing, the mass media consequently reported the whole event as scientifically premature. Professor I.L. Weismann, a nestor in stem cell research, denounced the whole story as a "non-event". The venture capitalists did not respond in any supportive way and the intended revival of the first framing as scientific progress was once again overruled by moral concerns. The techniques were identical with the first steps in reproductive cloning - an issue highlighted around Christmas the same year with a series of equally premature pronouncements of the first human clone already in uterus. The suggested techno-fix was thus considered and denied as just another moral problem: Hubris, playing - or taking the place of - God. Mankind's attempt of a technofix creation was dammed as just as offensive as his research on God's own creations. The alternative point of passage was rejected as a new moral problem, rather than a smart technical solution to the old moral problems. The experienced staff was, however, prepared to counter that. Dr. Ronald Green, the founding director of Office of Genome Ethics under the Clinton Administration, was now Chair of A.C.T.'s own Ethical Advisory Board, and the Boards conclusions and recommendations were printed side by side with the reportage in Scientific American:

...unlike an embryo, a cloned organism is not the result of fertilization of an egg by a sperm. It is a new type of biological entity never before seen in nature... we preferred the term "activated egg", and we concluded that its characteristics did not preclude its use in work that might save the lives of children and adults (Scientific American, 2002).

A.C.T.' s Ethical Advisory Board was thus able to expel or disqualify the moral concern as a question of (mis) understanding more than of substance, and as such to be solved on the level of concepts, neither in the labs nor on the political scene. Preceded by the terms "derivation" and "regenerative medicine" this conceptual manoeuvre is a third major example of the "power of definition" (Wolpe and McGee, 2001). A.C.T.'s Ethical Board is just one among many examples of how U.S. bioethicists, in addition to the few appointments to public commities (where they often express concern), are hired and employed as a profession on the level of labs and universities (where they often justify planned or ongoing research) (Donalson, 2001; 
Elliott, 2001). The supply of well-educated bioethicists has by far surpassed that of stem cell lines, and in the absence of a comprehensive national law in the US they often serve as "lawmakers" on the level of the firm. The old maxims of bioethics still dominating public discourse and the new profession of bioethicists increasingly employed in private frontline labs are thus drawing and drawn in each their direction, between concern and justification.

\section{The Political Ethics of Human Embryonic Stem Cells}

The five framings of human embryonic stem cells, presented and discussed above, did not originate and emanate from the science in the making in the labs; nor were they orchestrated by a single network or a single set of homogeneous agents; nor did they succeed each other successfully rendering the former superfluous. The two initial framings, as progress in basic science and hope of medical cure, were motivated and stirred by the entrepreneurs to avoid the experiences from the public debate following previous progress in biotechnology, but the public and political debate overruled the intention and strategy by the third framing as a moral concern. The two remaining framings representing adult stem cells and therapeutic cloning as alternative points of passage and solutions, redirected the debate to the level of the labs and the entrepreneurs, but they did not succeed to dominate and even less to close the debate - at least up until now.

The five framings do still coexist in an unsettled and unclosed tension, but the framings and their implications differ in such a profound way, that the question as to whether (and if so, how) they can really all refer back to the very same "clonogenic cells" nearly poses itself. Is the diversity of framings just a mere and fair reflection of the still un-described potentials inherent in the unique cells? Is the multitude of framings better interpreted as an expression of the many external interests involved in the political decisions? Should the disparity between the framings rather be seen as an echo of the plurality and relativism in postmodern optics? Might the many, still competing, framings be a mere consequence of the fact that the unique cells only recently were constituted as object for science, a question of time soon to be resolved? Or could it be that there is no one single and well-defined biological entity behind the five framings?

Professions and experts have often claimed a normative priority or even precedents on behalf of "their" framing: for science as the necessary precondition; for medicine as the ultimate goal; for ethics as the absolute limit to all the others; for adult stem cells as the ultimate and for the techno-fix as the smartest solution. None of the framings have, however, attained any such priority. All have been part of an encounter for a truthful understanding and a fair evaluation, but none of them have had the power or influence to prescribe their understanding as unequivocal. The framings never posed a single agenda; nor did they determine a corresponding evaluation. Political interests and compromises have consequently over-determined, tinted and intermixed, the five framings from the very beginning. The presentation of the scientific breakthrough was co-determined by the re- 
quirements for funding and patents. The medical hope was embedded in general changes of life-style. Ethical recommendations were altered according to political appointments. Adult stem cells and cloning/parthenogenesis were instantly presented to politics as possible solutions to the ethical concerns.

Sheila Jasanoff has mapped and emphasized substantial national differences in the American, British and German regulation of biotechnology (Jasanoff, 1995). Unrelated shifts of governments in the three nations during the early years of human embryonic stem cells have, however, shaped noteworthy shifts within the national regulations. The U.S.A. has turned towards a more restrictive and Germany towards a more permissive regulation whereas Great Britain represents a national continuity.

The British continuity is firmly rooted in the nation's customary scientific selfunderstanding and institutionalized through the Warnock-Committee, the subsequent Human Fertilisation and Embryology Act and its corresponding executive body The Human Fertilisation \& Embryology Authority (Mulkay, 1997). Within this framework Tony Blair's new Labour-government could turn to The Chief Medical Officer for a delimited and authoritative examination. Neither government nor the parliamentary majority had problems in following the predictable recommendation that "research using embryos $[\ldots]$ to increase understanding about human disease and disorders and their cell-based treatment should be permitted subject to the controls of the Human Fertilisation and Embryology Act". The only additional step needed was the Human reproductive Cloning Act of 2001 that prohibited "the placing in a woman of a human embryo which has been created otherwise than by fertilization" i.e. by reproductive cloning.

Following the President's broadcasted address on August 9, 2001, the U.S.A. implemented a new advisory structure. An Executive Order of Nov. 28 established The President's Council on Bioethics headed by the well-known conservative bioethicist Professor Leon Kass (Kass, 2001). Seventeen additional members were appointed on January 16, 2002. The President addressed them the following day (Bush, 2002) and the Council's report Human Cloning and Human Dignity: An Ethical Inquiry was published in July the same year. The Council was unanimous to refuse "cloning-to-produce-children" (reproductive cloning), but split regarding "cloning-for-biomedical-research" (therapeutic cloning). A majority of ten recommended "a four-year moratorium", whereas a minority of seven recommended "regulation on the use of cloned embryos for biomedical research" (The President's Council on Bioethics, 2002). Accordance between the President's policy and (the majority of) his ethical advisors was thus re-established. A recent reconstruction of the decision making process and its procedure by Alta Charo, a member of President Clinton's National Bioethics Advisory Commission (1996-2001), concludes that what distinguishes President Bush's new Council from the former "is not that it incorporates politics into its work, but that it does so with a concerted effort to promote a particular political philosophy, and pursues this philosophy through its membership and its staffing". Her final deep sigh that the most vibrant and enduring debates "are not at all about the 
ethics of biology or medicine, but the ethics of governance" (Charo, 2004: 308, 312 ) is in full harmony with the above findings.

Following Helmut Kohl's CDU-government Gerhard Schroeder's new SPDgovernment initiated the reverse shift towards a more permissive policy taken in Germany. The new Nationaler Ethikrat was appointed on April 25, 2001. Addressed by the Chancellor at its first meeting on June 8 (Schroeder, 2001) and its report Stellungnahme zum Import menschlicher embryonaler Stamzellen was published the following summer. Fifteen members voted in favour of "a provisional and temporary import of human embryonic stem cells on hard conditions", whereas ten members voted for "a provisional refusal of import of stem cells" (Nationaler Ethikrat, 2002). Accordance between the Chancellor's policy and (the majority of) his ethical advisors was thus re-established.

The unchanged British policy, the U.S. shift toward a more restrictive and the German toward a more permissive policy, are good illustrations of how effected even the principles of bioethics have been by national differences and political conjunctures. Bioethics often argue in a strong rhetoric and with absolute arguments, but they have never been unambiguous, nor a decisive or even superseding argument in political decisions. Shifting politicians have repeatedly appointed their bioethical advisors in accordance with predetermined policies. Bioethics has always also been political. The (Christian) argument from status and the (Kantian) maxim of means-ends have been powerful rhetorical tools, but pragmatic and utilitarian ethics have had a greater impact on political decisions. The considerations of political bioethics have gradually turned from the status of the biological substances and general maxims towards the more comprehensive questions of society's justice and the individual's identity. Possible consequences for society at large, i.e. the possibility of a more hierarchical and competitive post-human world, and the emergence of a new, liberal and unintended eugenics, have gained increased attention. Fukuyama, a U.S. neo-liberal and a member of the Bush Council, argues that what ought to be the real cause of worry are the "monsters we will soon be capable of creating," not the sources of stem cells. "The posthuman world could be one that is far more hierarchical and competitive than the one that currently exists, and full of social conflicts as a result" (Fukuyama, 2002: 91, 218). Jürgen Habermas (2003), a German philosopher in the tradition of the Frankfurt School, questions the identity of individuals whose genetic makeup has been pre-selected or premanipulated as an issue of "Gattungsethik".

Most policy decisions and regulations have been open and pragmatic enough to enable two apparently opposed, but coexisting critiques: one aimed at the use of dual or double "moral" standards voiced mainly by religious communities, and another aimed at the too restrictive regulations and voiced mainly by the scientific communities and business.

The Presidential decision permitted the use of old embryonic stem cell lines dating back before the speech of August 9, 2001 "where the life and death decision has already been made". The new German Law permitted the use of imported stem cell lines. Already existing 
and imported cell lines are both pragmatic loopholes, without which the criticism for too restrictive policies would have been even more vociferous, but political regulations have nonetheless increasingly been used to excuse and explain away disappointed or postponed hopes and expectations. The initial framings are thus twisted to the argument that politicians giving too many concessions to the ethical concerns are the prime cause of the still unfulfilled expectations. The disappointment is thus presented as a matter of time, not of principle; a question of delay, not of unsolvable problems. Had science only had the freedom to follow its course, promises and expectations would already have been fulfilled! A hypothetical bogey is thus turned into a partial excuse.

\section{Entity or State?}

Representing a radical version of the "extended social constructivism", presented earlier by Pinch and Bijker, John Law has drawn the methodological implication that "... from the standpoint of the network those elements that are human or social do not necessarily differ in kind from those that are natural and technological" [...] "it makes sense to treat natural and social adversaries in terms of the same analytical vocabulary" (Law, 1989: 114). Yet, the difference between Bijker and Pinch's use of the term "framing" to indicate different designs and inventions and the five framings of what is expected to be the same biological entity, discussed here, suggests important differences between the design of "technological artefacts" (as the bicycle and Bakelite) and the derivation of an "en- tity of nature" (as embryonic stem cells). Both are open to interpretative "flexibility", but natural "facts" appear less open to design than technological "artefacts" and social "constructs", and it appears that natural entities can be "stabilized" without a closure of the debate and controversy over them.

Culminating in the so called "science war", representatives of the hard sciences have repeatedly criticized radical social constructivism as mere relativistic or even subjectivistic, as the precedence of sociology of knowledge over epistemology, and thus also of power over truth. A recent review article by the geneticist and system-biologist Dov Zipori suggests, however, "state" rather than "entity" as the real "nature" or true interpretation of embryonic stem cells. The transient stem cell state, termed the "stem state", may be assumed by any cell and the persistent search for specific genes expressed by any stem cells, might thus be futile, doomed to become unsuccessful. Following Zipori, stem cells are just a "molecular configuration" without permanent characteristics, which should be identified or predicted by system-biology tools, i.e. overall genomic and proteomic analysis coupled with mathematical modeling (Zipori, 2004: 873).

Zipori's system-biological reinterpretation of embryonic stem cells, emphasizing the state rather than the entity, the biological environment rather than the genetic make-up, represents an ironic twist and implicit concession to the radical social constructivists and offers a possible explanation to the diversity of framings. Stem cells as just a state instead of a specific type of cells, makes the apparent "triviality" of their derivation 
less mysterious. Stem cells as "stemness" dissolve the alleged differences in potentiality between embryonic and adult stem cells, and dissolute the alternative between embryonic stem cells as either an ontological hierarchy or pure plasticity dissolute. The moral discussion, which presupposes or ascribes a specific "ethical" nature or validity of embryonic as opposed to adult stem cells, appears even more ungrounded and futile than implied above. Science's editorial stand back in 1999 that stem cells "forces scientists to reconsider fundamental ideas about how cells grow up" (Vogel, 1999) might have more profound and farreaching implications than fainted and glimpsed hitherto.

\section{Acknowledgements}

Research for this article was supported by a grant from The Research Council of Norway, Ethical, Legal and Social Aspects of Bio- and Gentechnology, ELSANorway (156232/510). Research, including site-visits and interviews at Geron Corporation and Advanced Cell Technology, started up under the hospitality of University of California, Berkeley, 2001-2002. Experiences from the Norwegian Biotechnology Advisory Board 2000-2004 are also reflected in the article. The author wants to thank Siv F. Berg, Ole Johan Borge, Troy Duster, Vidar Enebak, Karen Lebacqz, Ole Didrik Lærum, Esben A. Nilssen, Rune Nydal, Dorethy Olsen, Gisli Palsson, Antonio Regalada, Gunnar Skirbekk, Henrik Treimo, and Dov Zipori. A travel-grant was given by Etikkprogrammet, University of Oslo, Norway.

\section{Notes}

1 Further patents, licensing policies, the new importance of patents after the U.S. Presidential decision of August 9, 2001, and Geron's later patent strategy in cooperation with The Roslin Institute are described in Franklin (2003) and Rohrbaugh (2003).

\section{References}

American Association for the Advancement of Science

1999 Stem Cell Research and Applications. Washington, D.C.: National Academy Press.

Advanced Cell Technology InformationPacket. www.advancedcell. com. Various versions.

Alexander, B.

2003 Rapture. How Biotech Became the New Religion. New York: Basic Books.

Benford, R.D \& Snow, D.A.

2000 "Framing Processes and Social Movements: An Overview and Assessment". Annual Review of Sociology 26: 611-39. Bijker, W.E.

1987 "The Social Construction of Bakelite: Towards a Theory of Invention." Pp. 159-187 in W.E. Bijker, T.P. Hughes and T. Pinch (eds.), The Social Construction of Technological Systems. Cambridge \& London: The MIT Press.

Bush, G.W.

2001 Remarks by the President on Stem Cell Research. August 9. The White House.

2002 Remarks by the President in Meeting with Bioethics Committee. January 17. The White House.

Caplan A.L.

2004 "Stem-cell Research a Pawn in Election Politics". Bioethics.net. The American Journal of Bioethics. Posted 2004.10.05.

Charo, A.

2004 "Passing on the Right: Conservative Bioethics is Closer Than It Appears". Journal of Law, Medicine \& Ethics. 32: 307-314. 
Chui, A.Y. \& Rao, M.S. (eds.)

2003 Human Embryonic Stem Cells. New Jersey: Humana Press.

Cibelli J.B. et al.

2001 "Somatic Cell Nuclear Transfer in Humans: Pronuclear and Early Embryonic Development." E-biomed: The Journal of Regenerative Medicine. November 26. www.livertpub.com/ebl

Clarke, D. et al.

2001 "Generalized Potential of Adult Neural Stem Cells.” Science 2888, June 2: 16601663.

Coghlan, A. \& Young, E.

2001 "Adult Skin Cells are Turned Into Heart Cells Without Creating Embryos, Claim Scientists." New Scientist. Feb. 23.

Colter, C.C. et al.

2001 "Identification of a Subpopulation of Rapidly Self-renewing and Multipotential Adult Stem Cells in Colonies of Human Marrow Stromal Cells." Proceedings of the National Academy of Sciiences, USA, June 26.

Dwayne A.B. \& Fossel, M.

1989 "Telomeres, Cancer and Aging. Altering the Human Life Span." Journal of the American Medical Association, 278: 1345-48.

Donaldson, T.

2001 "The Business Ethics of Bioethics Consulting." Hastings Center Report 31(2): 12-19.

Elliott, C.

2001 "Throwing a Bone to the Watchdog. Bioethics in Business." Hastings Center Report 31(2): 9-12.

Evans, J.H.

2002 Playing God? Human Genetic Engineering and the Rationalization of Public Bioethical Debate. Chicago: The University of Chicago Press.

Evans, M.J. \& Kaufman, M.H.

1981 "Establishment in Culture of Pluripotential Cells From Mouse Embryo." Nature 292, July 9: 154-156.

Foucault, M.

1971 L'ordre du Discours. Paris: Editiones Gallimard.
Franklin, S.

2003 Ethical Biocapital. Pp. 97-127 in S. Franklin and M Lock (eds.), Remaking Life \& Death. Towards an Anthropology of the Biosciences. Santa Fe \& Oxford: School of American Research Press \& James Currey Ltd.

Fukuyama, F.

2002 Our Posthuman Future. New York: Farrar, Straus and Giroux.

Fucks, E. \& Segre, J.A.

2000 "Stem Cells: A New Lease on Life". Cell. 100: 143-155.

Garr, D.

2001 "The Human Body Shop". Technology Review, April: 73-79.

Gould, S.J.

2001 "What Only the Embryo Knows". The New York Times. Aug. 27.

Green, R.M.

2001 The Human Embryo Research Debates. Bioethics in the Vortex of Controversy. Oxford: Oxford University Press.

Habermas, J.

2003 The Future of Human Nature. Cambridge: Polity.

Hall, S.S.

2003 Merchants of Immortality. Chasing the Dream of Human Life Extension. Boston: Houghton Mifflin Company.

Holden, C. \& Vogel, G.

2002 "Plasticity: Time for Reappraisal?" Science. Vol. 296, June 21: 2126-2129.

Jasanoff, S.

1995 Product, Process, or Programme: Three Cultures and the Regulation of Biotechnology. Pp. 311-331 in M. Bauer (ed.), Resistance to new Technology. CamKater, L. bridge: Cambridge University Press.

2004 "Emerging Stem Cell Strategies: Practices, Rhetorics \& Policies". Report from the joint $4 \mathrm{~S} \&$ EASST Conference, Au-

Kass, L. gust 2004.

2001 "Why We Should Ban Cloning Now: Preventing a Brave New World". New Republic, May 21:30-39. 
Kerry, J. \& Edwards, J.

2004 Supporting Stem Cell Research to Find Cures For Millions Of Americans Suffering From Debilitating Diseases. Press Release. www.johnkerry.com/issues/health_care/stemcell.html

Kuhn, T.S.

1962 The Structure of Scientific Revolutions. Chicago: The University of Chicago Press.

Landecker, $\mathrm{H}$.

2003 On Beginning and Ending with Apoptosis. Cell Death and Biomedicine. Pp. 23-59 in S. Franklin and M Lock (eds), Remaking Life \& Death. Towards an Anthropology of the Biosciences. Santa Fe \& Oxford: School of American Research Press \& James Law, J. Currey Ltd.

1987 "Technology and Heterogeneous Engineering: The Case of Portuguese Expansion." Pp.111-134 in W. E. Bijker, T. P. Hughes and T. Pinch (eds), The Social Construction of Technological Systems. Cambridge \& London: The MIT Press.

Lebacqz, K. et al.

1999 "Research with Human Embryonic Stem Cells: Ethical Considerations." Hasting Center Report. 29, 2:31-36.

Martin, G.R.

1981 "Isolation of Pluripotent Cell Line From Early Mouse Embryos Cultivated in Medium Conditioned by Teratocarcioma Stem Cells." Proceedings of the National Academy of Sciences 78(12): 7634-7638.

Mulkay, M.

1997 The Embryo Research Debate. Science and the politics of Reproduction. Cambridge: Cambridge University Press.

National Institute of Health

2000 Stem cells: A Primer. http://www.nih. gov/news/stemcell/primer.htm

National Research Council

2001 Stem Cells and the Future of Regenerative Medicine. Washington D. C.: National Academy Press.
Nationaler Ethikrat

2002 Stellungnahme zum Import menschlicher embryonaler Stamzellen. (Position on Import of Human Embryonic Stem Cells).

The New York Times

1998 "Scientists Cultivate the Cells From Which Human Life." Nov 6: 1-2.

Okarma, T.B.

2001 "Human Embryonic Stem Cells: A Primer on the Technology and its Medical Applications". Pp. 3-13 in S. Hollander, K. Lebacqz and L. Zoloth (eds.), The Human Embryonic Stem Cell Debate. Cambridge \& London: The MIT Press.

Perry, D.

2000 "Patient's Voices: The Powerful Sound in the Stem Cell Debate." Science, 287: 1423.

Pinch, T.J. \& Bijker, W.E.

1987 "The Social Construction of Facts and Artifacts: Or How the Sociology of Science and the Sociology of Technology Might Benefit Each Other." Pp. 18-50 in W. E. Bijker, T. P. Hughes and T. Pinch (eds), The Social Construction of Technological Systems. Cambridge \& London: The MIT Press.

The President's Council on Bioethics

2002 Human Cloning and Human Dignity: En Ethical Enquiry. Washington, D. C.: Government Printing Office.

Regalado, A.

1998 "The Troubled Hunt for the Ultimate Cell.” Technology Review. July-August: 4-41.

Rohrbaugh, M.L.

2003 Intellectual Property of Human Pluripotent Stem Cells. Pp. 39-60 in A.Y. Chui and M. S. Rao (eds.), Human Embryonic Stem Cells. New Jersey: Humana Press.

Scientific American

2002 "The First Human Clone. The Clone Makers Tell Their Story." January: Frontpage \& 43-51.

Schroeder, G.

2001 "Rede des Bundeskanzler zur konstituierenden Sitzung". (Address of the Chancellor to Constitutive Meeting). Bulletin der Bundesregierung. Nr. 393. www.ethikrat.org/publikationen/ reden/bundeskanzler 
Scolding, N.

2001 "New Cells From Old." The Lancet, 357. Feb. 3.

Shamblott, M.J. et al.

1998 "Derivation of Pluripotent Stem Cells From Cultured Human Primordial Germ Cells". Proceedings of the National Academy of Sciences 95: 1372613731.

Thomsen, J.A.

2001 "Human Embryonic Stem Cells". Pp. 15-26 in S. Hollander et al. (eds.), The Human Embryonic Stem Cell Debate. Cambridge \& London: The MIT Press.

Thomson, J.A. et al.

1995 "Isolation of a Primate Embryonic Stem Cell Line.” Proceedings of the National Academy of Sciences 92: 7844-7848.

1998 Embryonic Stem Cell Lines Derived from Human Blastocysts. Science 282 (6): 1145-1147.

United States Patent

1998a Human embryonic germ cell line and methods of use. Patent number 6,245,566 filed March 31; approved June 21, 2001.

1998b Primate embryonic stem cells. Patent number 6,200,806 filed June 26; apVogel, G. proved March 13, 2001.

1999 "Capturing the Promise of Youth." Science, 286: 2238-2239.

Weismann, I.L.

2000 "Stem Cells: Unit of Development, Unit of Regeneration, and Unit in Evolution." Cell.100: 157-168.

West, M.D.

2003 The Immortal Cell. One Scientist's Quest to Solve the Mystery of Human Aging. New York: Doubleday.

Wilmut, I. et al.

1997 "Viable Offspring Derived From Fetal and Adult Mammalian Cells." Nature, 385: 810-813.

Wolpe, P.R. \& McGee, G.

2001 “'Expert Bioethics' as Professional Discource: The Case of Stem Cells." Pp. 185-207 in S. Holland, K. Lebacqz and L. Zoloth (eds.), The Human Embryonic Stem Cell Debate. Cambridge \& London: The MIT Press.
Zipori, D.

2004 "The Nature of Stem Cells: State Rather Than Entity." Nature Reviews. Genetics. 5: 873-878

2005 "The Stem State: Plasticity is Essential, While Self-renewal and Hierarchy are Optional." Manuscript in preparation. Rehovot, Israel.

\section{Torben Hviid Nielsen}

Center for Technology, Innovation

and Culture

University of Oslo

t.h.nielsen@tik.uio.no 